\title{
Evaluation of electricity consumption of a residential flat in Egypt
}

\author{
Mofreh M. Nassief \\ Faculty of Engineering Zagazig University Egypt \\ Email address: \\ Mofreh_melad@yahoo.com \\ To cite this article: \\ Mofreh M. Nassief. Evaluation of Electricity Consumption of a Residential Flat in Egypt. American Journal of Electrical Power and \\ Energy Systems. Vol. 3, No. 2, 2014, pp. 37-44. doi: 10.11648/j.epes.20140302.14
}

\begin{abstract}
Energy saving is one of the most important demands in our world .The aim of this paper is to evaluate the annual electrical energy consumption of a residential flat in EGYPT and how to reduce it. This evaluation includes the compatibility of a flat for the Egyptian code requirements of residential buildings. This flat is of a total area of $160 \mathrm{~m}^{2}$ with one façade opening. A software package Visual-Doe 4.0 was used for this analysis. Three different climatic regions were used for this analysis: Cairo, Alexandria and Aswan cities with different weather conditions (due to their geographical location on latitude $30.1,31.2$ and 24 respectively). The results give the minimum requirements of walls insulation $(2.5 \mathrm{~cm})$ for different orientation and different climatic location. Also an average maximum reduction of about $17.11 \%$ of the total electrical energy consumption with insulation $5 \mathrm{~cm}$ compared to the actual consumption is fulfilled.
\end{abstract}

Keywords: HVAC, Systems, Electricity, Consumption, Thermal, Insulation

\section{Introduction}

Buildings sector today represents $40 \%$ of world's energy demand, $33 \%$ in commercial buildings and $67 \%$ in residential ones according to the Economic Co-operation and Development Organization (ECDO). The effort announced today for transforming the way buildings are conceived, constructed, operated and dismantled has ambitious targets. By 2050 new buildings will consume zero net energy from external power supplies and produce zero net carbon dioxide emissions while being economically viable to construct and operate Guirguis [5].

K.F.Fong et al.[11] proposed a hybrid renewable cooling system (HRCS) for office building application by utilizing both the solar energy and the ground source, in the HRCS appropriate design and operation between the groundsource radiant cooling and the solar absorption cooling was worked out. It was found that the HRCS could have $43.8 \%$, $53.3 \%$ and $68 \%$ primary energy saving when compared to the sole ground -source heat pump system, the sole solar absorption cooling system and the conventional vapor compression air -conditioning system respectively

Burton et al. discussed an experimental technique to investigate the optimum speed (for thermal comfort) of a ceiling mounted fan at various temperatures. The experiments took place in an office without windows and known width and heights. Results indicate that the effect of temperature on optimum for speed was highly significant.

Baker et al. summarized the results drawn from a series of field studies in predominantly overheated circumstances in order to develop the application of passive cooling techniques in southern Europe and also to develop suitable criteria for assessing proposed buildings. The results indicated that field studies failed to show directly the difference in predicated and observed room conditions.

Green building is the practice of increasing the efficiency of new buildings, and reducing their impact on human health and the environment through better site location, design, construction, operation and maintenance, Building_Codes.pdf, 2008.

Hanna et al. [6] studied the effect of building envelope to save energy associated with the total electricity consumed for residential buildings in Egypt (Cairo and Alexandria cities). The analysis shows that the over-all thermal transfer value (OTTV) for the exterior walls should not exceed 30 $\mathrm{W} / \mathrm{m}^{2}$ for Cairo but Alexandria does not need any insulation. The roof needs $50 \mathrm{~mm}$ insulation to reach $25 \mathrm{~W} / \mathrm{m}^{2}$.

Hanna et al. [6] summarized the results of energy simulation analysis to determine the effectiveness of building characteristics in reducing electrical energy consumption and saving for office building in Egypt. The 
simulation includes different variables such as window to wall area ratio, shading, light power density, different HVAC systems and window type. The main conclusion of these results is that a significant energy saving can be achieved by selecting materials with appropriate design techniques.

Sheble [13] evaluates the effect of window to wall area ratio (WWR) for different buildings types to save energy associated with the total electricity consumed. The analysis was agreed for different outdoor climate conditions in Egypt. The results show that decreasing the WWR generally saves more energy. For the very hot dry region it is recommended to reduce the WWR and prevention of natural ventilation during the day. The WWR up to $20 \%$ is preferred for commercial buildings to have energy efficiency.

Karlsson et al. [12] agreed a comprehensive investigation of a low-energy building. The ventilation rates, energy performance, occupants, perception of the indoor climate, and finally the environmental performance, with respect to $\mathrm{CO} 2$-emissions were investigated to study the buildings at different system levels. The results show that the heating and ventilation system can be improved to prevent draughts and ventilation short-cuts, and the heating system could be changed to district heating to achieve lower $\mathrm{CO} 2$ emissions and minimize the environmental impact. The pay-back period, with today's Swedish electricity prices for a building like this is about 19.5 years compared with a comparable Swedish building, within reasonable limits. If the electricity price is assumed to increase with $5 \%$ /yearly in the future, as the case has been during the last 5 years in Sweden, the pay-off time will decrease to about 14 years.

Wang et al.[16] discussed possible solutions for zero energy building design in UK. Simulation software Energy Plus and TRNSYS 16 are used in this study, where Energy Plus simulations are applied to enable facade design studies considering building materials, window sizes and orientations. TRNSYS is used for the investigation of the feasibility of zero energy houses with renewable electricity, solar hot water system and energy efficiency heating systems under Cardiff weather conditions. Various design methods are compared and optimal design for typical homes and energy systems are provided.

Virta1 et al. [14] presented energy simulation of office buildings located in France. It takes into account the energy consumption of different HVAC systems. Two different kinds of buildings have been used. Reference building has external structures of a typical new building in Paris today. In advanced building external walls and windows have lower U-value and improved tightness. Windows have also better shading coefficient and external overhang of $500 \mathrm{~mm}$ for solar shading. Result shows that with right HVAC system and building design can reduce energy consumption nearly $75 \%$.

Guirguis [5] shows a remarkable effect of the building envelope construction on the electricity consumption for different weather cities in Egypt. The prefabricated panel with $10 \mathrm{~cm}$ insulation gives lower electricity consumption and higher energy saving reaches up to $40 \%$ in comparison with other higher U-value brick walls. The wall insulation gives energy saving nearly $40 \%, 33 \%$ and $41 \%$ for Cairo, Alexandria and Aswan cities respectively.

\section{Theoretical Work}

In this present analysis the Visual-Doe program,2007 is one of the Green Design tools software programs that enable the architects, engineers and energy analysts to quickly evaluate the energy savings of building design options. The program uses the hourly simulation tools as the calculation engine so that energy use and peak demand are accurately evaluated on an hourly basis and annual electricity calculations. Different building shapes can be created. This program includes library for data entry such as building constructions, HVAC systems, lighting and equipment. All can be controlled using operating schedules during the year. Here after, the equations used in this analysis, ASHRAE Handbook Code of thermal insulation, 2007,Ventilating Engineering Guide,1970, ECP306/1, 2005.

a) Total thermal resistance $\left(\mathrm{R}_{\mathrm{t}}\right)$ which is the sum of all thermal resistances for a composed wall beside and outside surface thermal resistances, So

$$
\mathrm{R}_{\mathrm{t}}=\mathrm{R}_{\mathrm{so}}+\mathrm{R}_{1}+\mathrm{R}_{2}+\ldots \mathrm{R}_{\mathrm{n}}+\mathrm{R}_{\mathrm{si}},\left(\mathrm{m}^{2{ }^{\circ}} \mathrm{C} / \mathrm{W}\right)
$$

Where:

$$
\mathrm{Rso}=1 /(€ \mathrm{hr}+\mathrm{ho}) \quad \& \quad \mathrm{Rsi}=1 /(1.2 € \mathrm{hr}+\mathrm{hi})
$$

b) Thermal transmittance for a wall (U) which is the quantity of heat passing through a unit area of wall per unit time normally when there is a unit difference in temperature of inside \& outside, So

$$
\mathrm{U}=1 / \mathrm{R}_{\mathrm{t}}
$$

Also, the total transmittance $\left(\mathrm{U}_{\mathrm{o}}\right)$ for walls contain openings like Windows, Doors, Balconies, etc, can be calculated from.

$$
\mathrm{U}_{\mathrm{o}}=\Sigma\left(\mathrm{A}_{\mathrm{w}} \cdot \mathrm{U}_{\mathrm{w}}+\mathrm{A}_{\mathrm{d}} \cdot \mathrm{U}_{\mathrm{d}}+\mathrm{A}_{\mathrm{g}} \cdot \mathrm{U}_{\mathrm{g}}+\ldots\right) /\left(\mathrm{A}_{\mathrm{w}}+\mathrm{A}_{\mathrm{d}}+\mathrm{A}_{\mathrm{g}}+\ldots\right),\left(\mathrm{W} / \mathrm{m}^{2{ }^{\circ}} \mathrm{C}\right)
$$

c) Energy Savings " $Q_{\text {saving }}$ ", (kW hour/m²/year)

The main goal for thermal insulation in buildings is the reduction of heat transfer which results in improving the inside environment of a building also in saving of electrical and thermal energies, so the quantity of energy per year can be calculated from

$$
\mathrm{Q}_{\text {saving }}=\left(\mathrm{U}_{\text {before insulation }}-\mathrm{U}_{\text {after insulation }}\right) \times \mathrm{DD} \times 24 \times 10^{-3}
$$


Where:

$$
\mathrm{DD}=\Sigma_{(24 \text { hours })}\left|\mathrm{T}_{\mathrm{b}}-\mathrm{T}_{\mathrm{o}}\right|,\left({ }^{\mathrm{o}} \mathrm{C} / \text { day }\right)
$$

The simulated flat is of total area about $160 \mathrm{~m}^{2}$ with ceiling height $3 \mathrm{~m}$. It consists of a hall, three rooms, a kitchen and a bath room as shown in Fig. 1. (The main façade containing four windows). The two sides and back walls are surrounded with adjacent flat walls which can be classified as adiabatic walls.
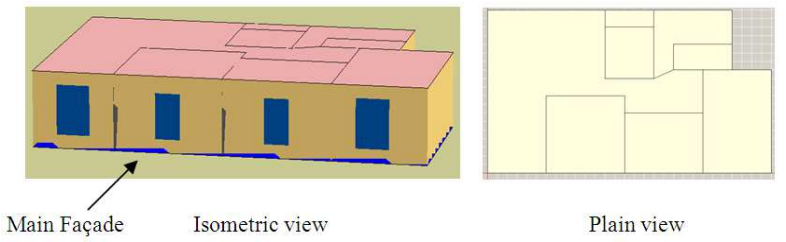

Figure 1. Sketch diagram of a single flat model with total area $160 \mathrm{~m}^{2}$ and height $3 \mathrm{~m}$.

In this work we simulate different walls and insulations (as shown in Fig. 2). The simulation includes also roof insulation, the roof construction is shown in Fig. 3. The annual total electricity was evaluated. The simulations were applied for different climate regions, Cairo, Alexandria and Aswan using climatic data. Different flat orientations (East, East-North, North, North-West, West, South, South-West and South-East) take place to evaluate the suitable and less wall insulation thicknesses for each. Different HVAC systems, Visul DOE 4.0 User Manual, [15] were used in the simulation for comparison of energy consumption.

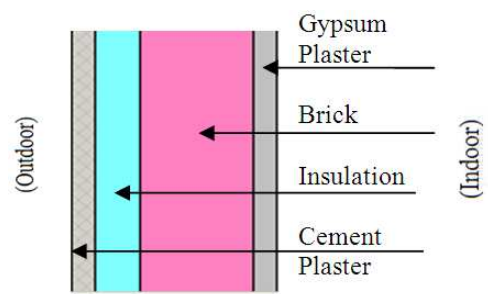

Figure 2. Wall construction.

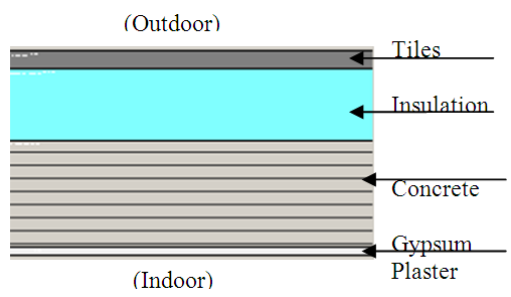

Figure 3. Roof construction.

Table 1 shows some information of basic design data about the components of HVAC systems taking in account heating max., supply air temp.is $46.1^{\circ} \mathrm{C}$ and the system of heating is "Furnace High". Its thermal efficiency is 0.8 .The auxiliary power is zero $\mathrm{kW}$, its pilot light power is $146.5 \mathrm{~W}$ and the baseboard source is hot water from plant. Cooling: min. supply temp is $12.8^{\circ} \mathrm{C}$ and the system of cooling is DX High Eff. Which has coil by pass factor of 0.19 Supply fan of mechanical, drive and motor efficiency of $0.55,0.95$ and 0.9 respectively and its static pressure is $497.6 \mathrm{pa}$

Table 1. Different HVAC systems used in the analysis.

\begin{tabular}{|c|c|c|c|}
\hline No. & System & Description of the main components & Diagram \\
\hline 1 & $\begin{array}{l}\text { Residential Variable Volume, } \\
\text { Variable Temp }\end{array}$ & $\begin{array}{l}\text { Economizer - heating and cooling units - supply fan - closed and } \\
\text { open loops }\end{array}$ & \\
\hline 2 & $\begin{array}{l}\text { Single Zone Variable } \\
\text { Temp }\end{array}$ & $\begin{array}{l}\text { Economizer - preheating - heating and cooling units - supply fan - } \\
\text { closed and open loops }\end{array}$ & \\
\hline 3 & Two Pipe Fan Coil & $\begin{array}{l}\text { Economizer-heating and cooling units - supply fan- closed and } \\
\text { open loops }\end{array}$ & \\
\hline 4 & Unit Heater & heating unit - supply fan - closed loop & \\
\hline 5 & Residential System & heating and cooling units -supply fan - closed loop & \\
\hline 6 & Unit Ventilator & heating unit - supply fan - closed and open loops & \\
\hline
\end{tabular}

\section{Results}

The HVAC system types and their options affect energy saving. Here in this research we use 6 different HAVC systems. The pre-heater components and open loops increase the energy consumption on the other side the closed loops reduce energy consumption. Also the flat orientation affects the energy consumption. To evaluate the effect of flat orientation with the energy consumption 
through the HVAC cooling system, the sides and rear walls are kept adiabatically ( 2.5 to $25 \mathrm{~cm}$ insulation thickness) with varying only the main façade wall constructions and insulation. Fig. 4 shows annual total electricity consumption of different HAVC systems for different climate regions in EGYPT (North direction).

The figure shows that the HAVC system number 2 (table 1) gives the maximum energy consumption than other systems due to the presence of the preheating unit and open loop. On the other hand, the HAVC system number 6 gives the lower energy consumption. Aswan city has maximum energy consumption because of its geographical location on latitude 24 and Alexandria has low energy consumption than other cities due to its geographical location on latitude 31.2. From the comparison of Figs. 4 to 11 for different flat orientation it is clear that the annual total electricity consumption for system 6 (unit ventilator HVAC system) is the least one of the 3 cities Aswan, Cairo and Alexandria respectively when the main façade is oriented to the North direction. Also the annual total electricity consumption for system 2 (Single zone variable temperature system) is the highest one of the 3 cities Alexandria, Cairo, Aswan respectively when the main façade is oriented to both East and West directions. The moderate annual total electricity consumption is for system number 1 (Residential variable volume, variable temperature),the other 3 systems numbers 3, 4 and 5 (two pipe fan, coil unit heater and residential system respectively) for the 3 cities and for all different climate regions in EGYPT are almost equal in the consumption of the annual total electricity . In addition, in all figures, it is clear that Alexandria is considered the least city in energy consumption (for different climate regions and different HVAC systems) this because of its geographical location, on adverse Aswan is considered the highest city in energy consumption (for different climate regions and different $\mathrm{HVAC}$ systems) this is because of its hot climate. Between the six different HVAC systems used in analysis, the unit ventilator HVAC system is chosen with different Air Change/Hour, ACH, because it satisfies the main goal of the research, that is saving energy.

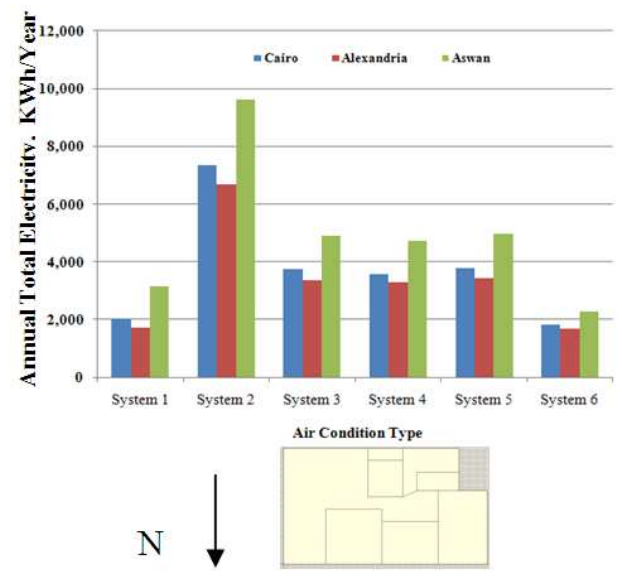

Figure 4. Annual total electricity consumption of different HAVC systems for different climate regions in EGYPT (North direction).

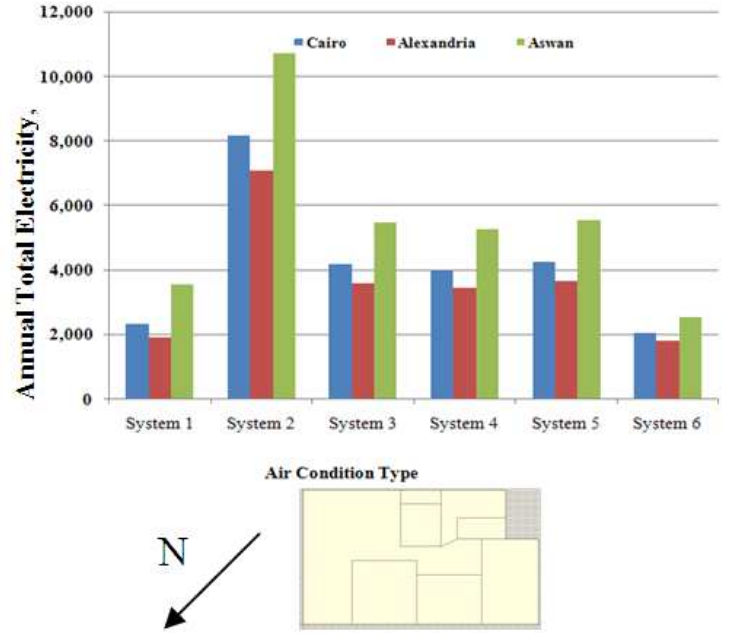

Figure 5. Annual total electricity consumption of different HAVC systems for different climate regions in EGYPT (North WEST direction).

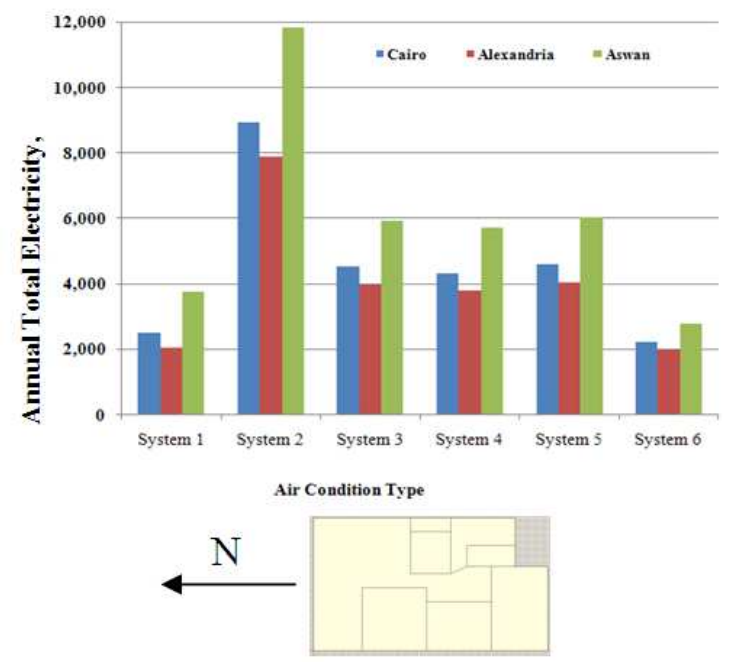

Figure 6. Annual total electricity consumption of different HAVC systems for different climate regions in EGYPT (West direction).

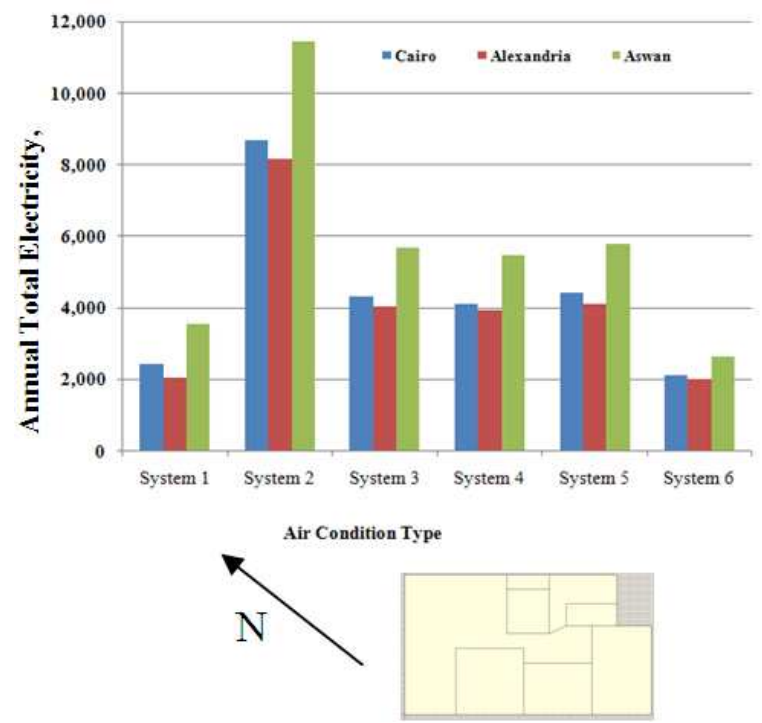

Figure 7. Annual total electricity consumption of different HAVC systems for different climate regions in EGYPT (South West direction) 


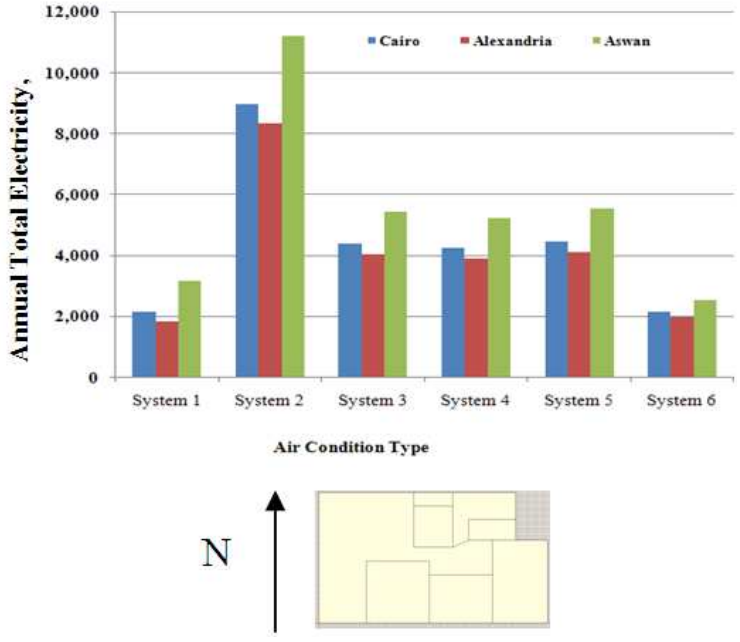

Figure 8. Annual total electricity consumption of different HAVC systems for different climate regions in EGYPT (South direction).

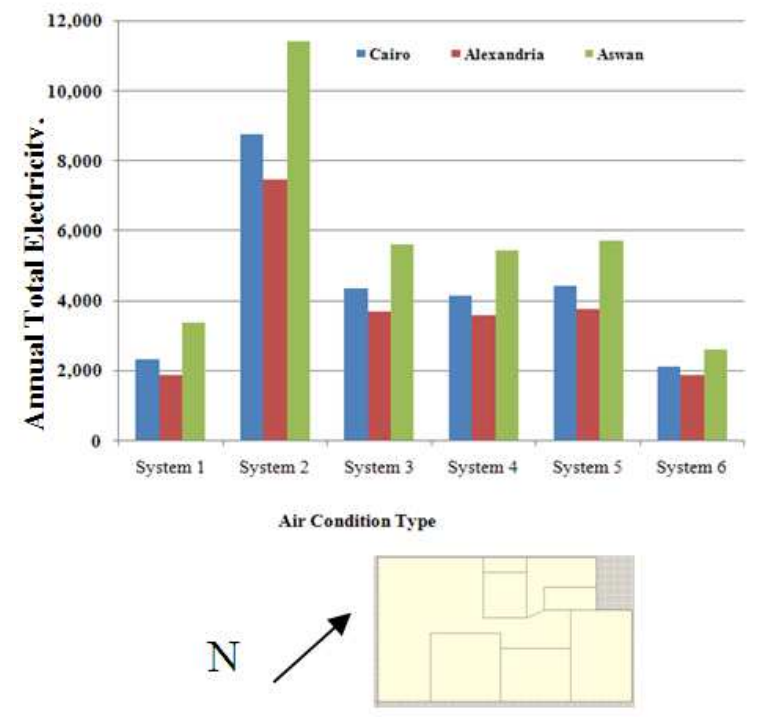

Figure 9. Annual total electricity consumption of different HAVC systems for different climate regions in EGYPT (South East direction)

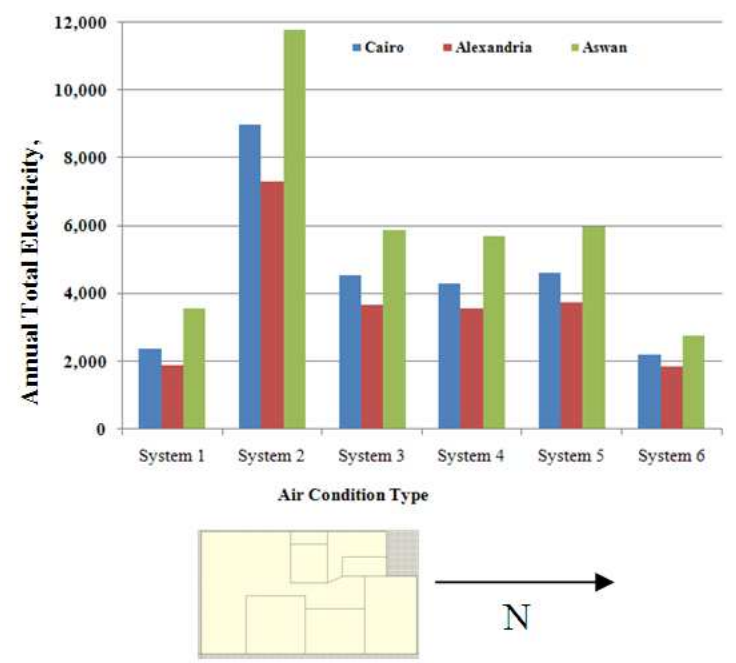

Figure 10. Annual total electricity consumption of different HAVC systems for different climate regions in EGYPT (East direction)

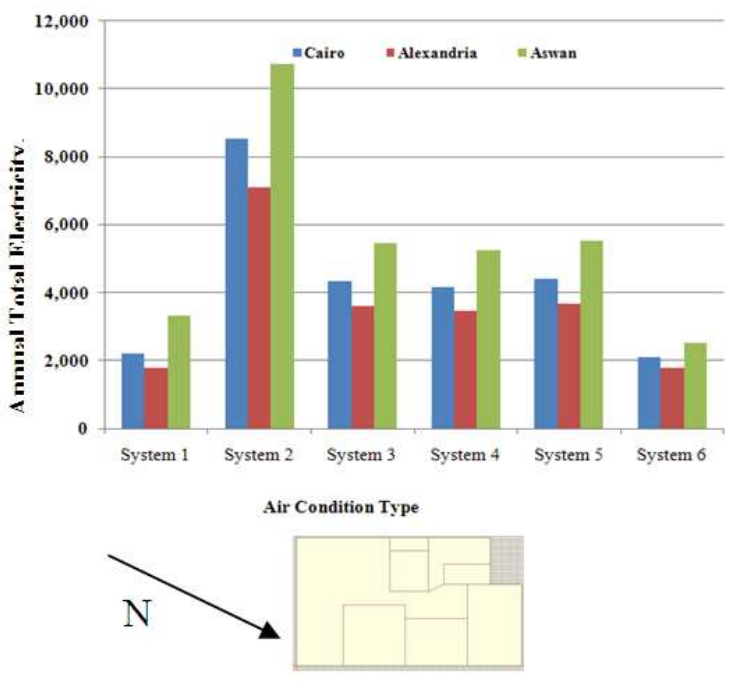

Figure 11. Annual total electricity consumption of different HAVC systems for different climate regions in EGYPT (North East direction).

Figs 12 to 19 show the annual total electricity energy consumption for both different $\mathrm{ACH}$ and climate regions in EGYPT (Cairo, Alexandria and Aswan) using the more economizer system for energy which is number 6 (the unit ventilator HAVC system) and the main façade of the study flat is oriented to different directions, North, North West, West, South West, South, South East, East and North East respectively. It is clear from the figures that as $\mathrm{ACH}$ increases the energy consumption increases. Also at Zero $\mathrm{ACH}$ for different directions, the annual total energy consumption for both Alexandria and Cairo approximately differs a little because of the difference in temperature during the year is approximately in the range of $3^{\circ} \mathrm{C}$ to 5 ${ }^{\circ} \mathrm{C}$ and due to the average rate of humidity during the year in Cairo is more than Alexandria \& Aswan, so with the increase of $\mathrm{ACH}$ the energy consumption increases, we find that the annual total energy consumption is approximately for Cairo 2.5 times for Aswan and 1.25 for Alexandria.

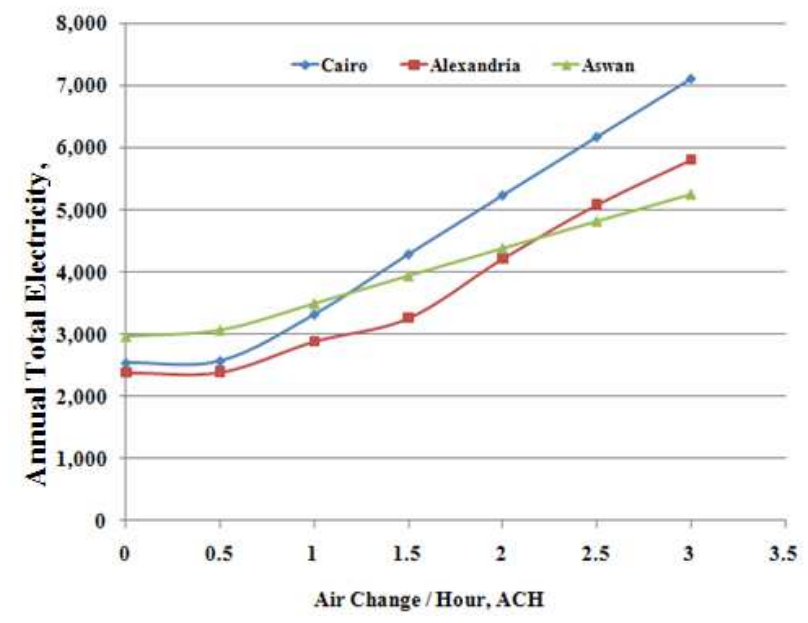

Figure 12. Annual total electricity consumption of ACH for different climate regions in EGYPT (North direction) 


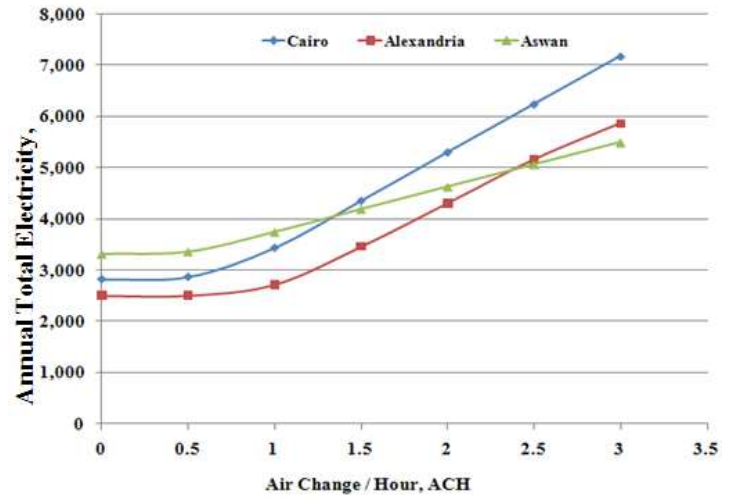

Figure 13. Annual total electricity consumption of ACH for different climate regions in EGYPT (North West direction).

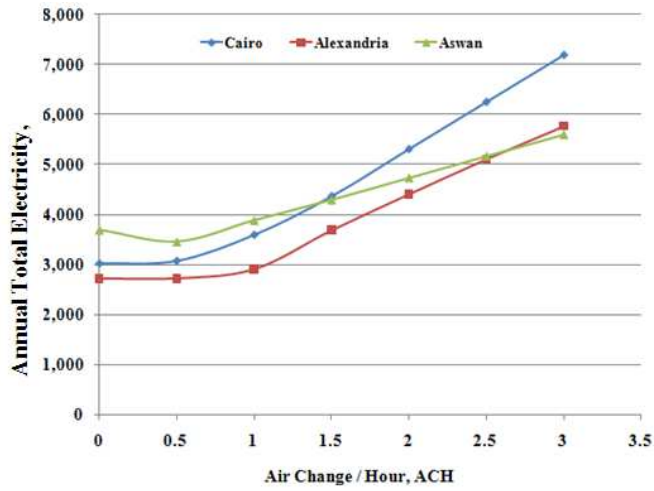

Figure 14. Annual total electricity consumption of ACH for different climate regions in EGYPT (West direction)

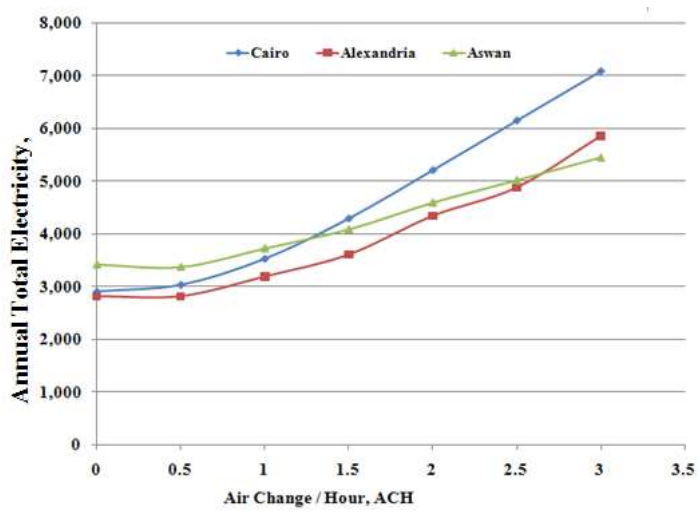

Figure 15. Annual total electricity consumption of ACH for different climate regions in EGYPT (South West direction)

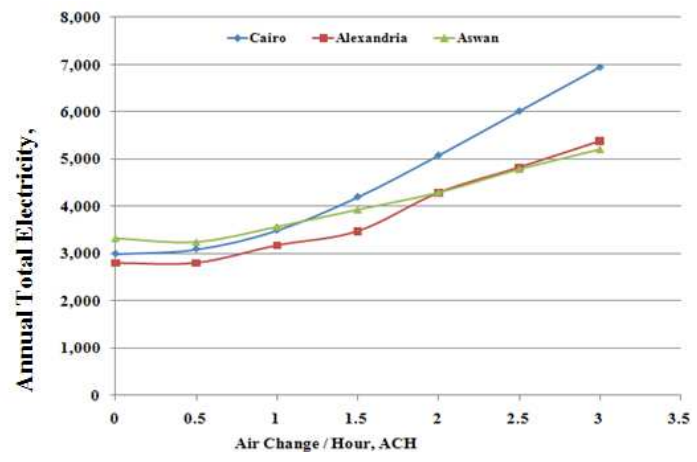

Figure 16. Annual total electricity consumption of ACH for different climate regions in EGYPT (South direction)

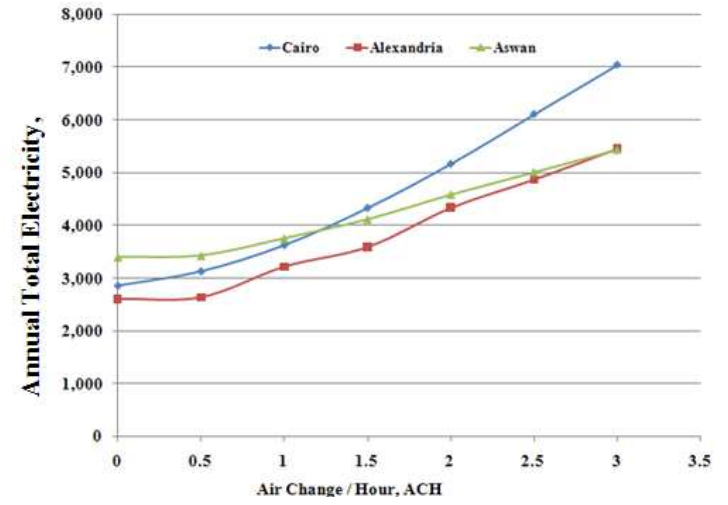

Figure 17. Annual total electricity consumption of ACH for different climate regions in EGYPT (South East direction)

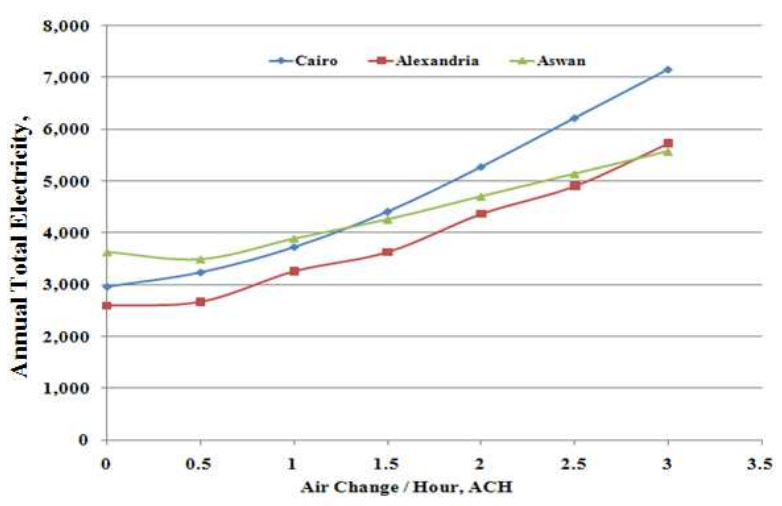

Figure 18. Annual total electricity consumption of ACH for different climate regions in EGYPT (East direction).

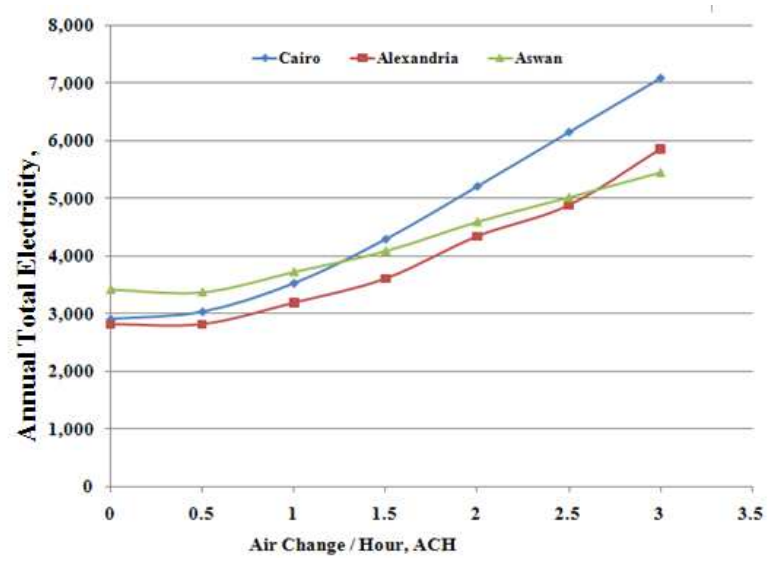

Figure 19. Annual total electricity consumption of ACH for different climate regions in EGYPT (North East direction).

Fig. 20 shows the annual total energy consumption for different wall insulation in Cairo for both different oriented directions (North, South, East and West) and R-value (thermal resistance). It is noted from figure that at zero insulation the energy consumption is relatively high for all directions but it is the least one for the North direction. Also as the insulation thickness increases the energy consumption decreases and the R-value increases. Finally the best oriented direction for façade is the North direction for both energy consumption and R-value. 


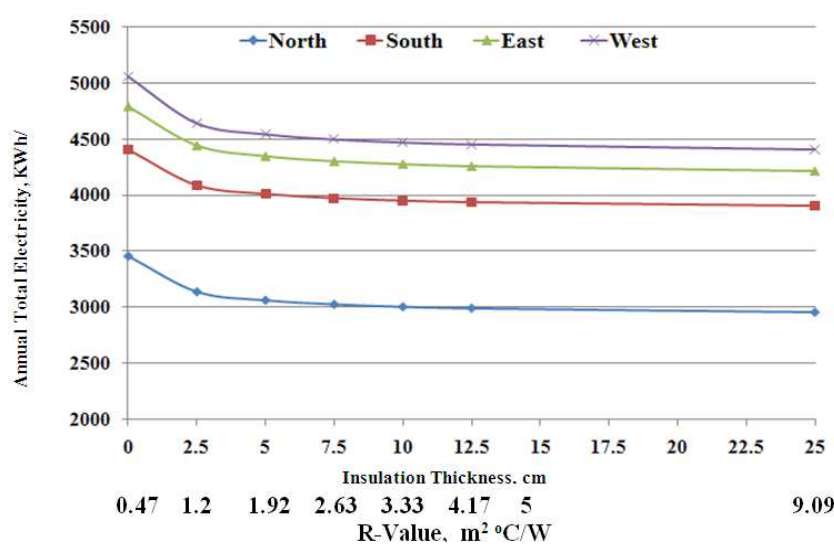

Figure 20. Annual total electricity consumption for different wall insulation thickness Cairo-EGYPT

Fig 21 shows a comparison between the actual case and the case study with and without insulation of the annual total electric energy consumption. It is clear that the maximum consumption of energy is at July (because of the average higher temperature in this month) and the consumption is reduced with $5 \mathrm{~cm}$ insulation by $17.11 \%$ compared to the actual case.

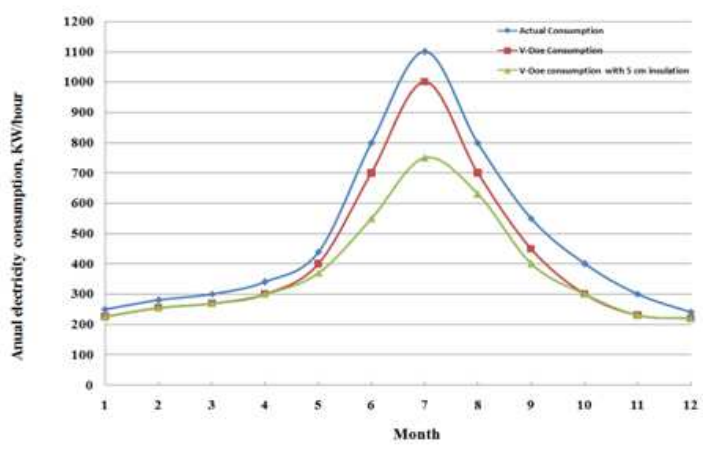

Figure 21. Monthly comparison between actual electricity consumption and the results obtained from $V-D O E$ with and without insulation for Cairo-EGYPT

The wall construction affects the thermal performance of buildings in which low thermal resistance(R-value) yields to more heat flow by conduction inside the building through walls. Thick construction or insulation (higher Rvalue) reduces the heat gain which reduces the indoor air temperature inside the buildings, as illustrated in table (2) . In this table there is a compression between the values of $\mathrm{R}$ for two different thickness of insulation $(2.5$ and $5 \mathrm{~cm})$ for the flat in Cairo city and the values that satisfy the requirement of Egyptian energy code ECP, 2005.

Table 2. Requirements of satisfaction of the energy efficiency of the external walls according to Egyptian energy code (ECP), Absorptive $=0.38, \quad$ West direction, $W W R>30 \%$

\begin{tabular}{ccccc}
\hline Zone & \multirow{2}{*}{ R- value according to ECP } & \multirow{2}{*}{ R- value without insulation } & \multicolumn{2}{c}{ R- value with insulation } \\
& & & $2.5 \mathrm{~cm}$ & $5 \mathrm{~cm}$ \\
\hline Cairo & 1.07 & 0.47 & 1.2 & 1.92 \\
\hline
\end{tabular}

\section{Conclusions}

1-The research shows a noticeable effect of the building construction on the energy consumption for the different three cities of different weather.

2-Between the six HAVC systems used in analysis, the more economizer system for energy consumption is the unit ventilator HAVC system.

3-The North and North-East façade need less wall insulation than other façade.

4-The walls need more thick insulation especially in Aswan city.

5-As the thickness of insulation increases, the R-value increases and the annual energy consumption decreases especially for the North direction.

6-For zero insulation the R-value and the annual total electricity are maximum for the four directions, North, South, East, and West, but the West direction is the most consumption for energy and the North direction is the least one.

7-Due to the average rate of humidity for Cairo during the year ( more than Aswan and Alexandria) the annual total energy consumption is approximately for Cairo 2.5 and 1.25 respectively times for Aswan and Alexandria.
8-The exposed East, West and South-West walls need more thick insulation especially for Cairo and Aswan cities.

9-By using $5 \mathrm{~cm}$ insulation thickness for the walls ,the annual total energy consumption is reduced approximately by $17.11 \%$.

\section{Footnotes}

$\mathrm{T}_{\mathrm{o}}$ : the daily average temperature, $\left({ }^{\circ} \mathrm{C}\right)$.

$\mathrm{T}_{\mathrm{b}}$ : base temperature, $\left(18.3{ }^{\circ} \mathrm{C}\right.$ for warming $\& 25^{\circ} \mathrm{C}$ for cooling).

DD:degree-day (the sum of temperature difference), $\left({ }^{\circ} \mathrm{C} /\right.$ day $)$.

$\mathrm{A}_{\mathrm{w}}$ : net area of solid walls, $\left(\mathrm{m}^{2}\right)$

$\mathrm{A}_{\mathrm{g}}$ : net area of glass openings, $\left(\mathrm{m}^{2}\right)$.

$A_{d}$ : net area of doors, $\left(\mathrm{m}^{2}\right)$.

$\mathrm{h}_{\mathrm{i}}, \mathrm{h}_{\mathrm{o}}$ : inside and outside surface thermal conductance, $\left(\mathrm{W} / \mathrm{m}^{2} \mathrm{C}\right)$.

$\mathrm{h}_{\mathrm{r}}$ : heat transfer coefficient by radiation, $\left(\mathrm{W} / \mathrm{m}^{2}{ }^{\circ} \mathrm{C}\right)$.

$\mathrm{R}_{\mathrm{t}}$ : Total thermal resistance, $\left(\mathrm{m}^{2 \mathrm{o}} \mathrm{C} / \mathrm{W}\right)$.

$\mathrm{R}$-value: Total thermal resistance of the composed wall $\left(\mathrm{m}^{2}\right.$ $\left.{ }^{\circ} \mathrm{C} / \mathrm{W}\right)$.

$\mathrm{U}_{\mathrm{w}}$ : total thermal transmittance for solid walls, $\left(\mathrm{W} / \mathrm{m}^{2}{ }^{\circ} \mathrm{C}\right)$

$\mathrm{U}_{\mathrm{g}}$ : total thermal transmittance for glass openings, $\left(\mathrm{W} / \mathrm{m}^{2}\right.$ ${ }^{\circ} \mathrm{C}$ ).

$\mathrm{U}_{\mathrm{d}}$ : total thermal transmittance for doors, $\left(\mathrm{W} / \mathrm{m}^{2}{ }^{\circ} \mathrm{C}\right)$. 
€: coefficient of emissivity, 0.9 for building materials, (non).

\section{Acknowledgement}

The author like to thank the team of aerodynamic lab. Housing \& Building National Research Center-Egypt and $\mathrm{Mr}$ Badr for their valuable help in this work

\section{References}

[1] ASHRAE Handbook Fundamentals,. American Society of Heating, Refrigerating and air-conditioning Engineering, 1997.

[2] Baker, N., Standeven, M.,"A Behavioral approach to thermal comfort assessment in naturally building", CIBSE National conference, 76-84, 1995.

[3] Burton, D.R., Robeson, K.A. and Nevius,R.G., "The effect of temperature on the preferred air velocity for sedentary subjects dressed in shorts", ASHRAE ,157-168,1975.

[4] Egyptian Energy Code Program (ECP) 306/1-2005,edition 2005.

[5] Guirguis, N.M., "Energy Efficiency of Flat for Different Egyptian Regions", World Renewable Energy Conference, WREC, Abu Dhabi,2010.

[6] Hanna, G.B., Guirguis, N.M., Osman, H.S., Hussein, M.A., " Energy analysis for new residential buildings in Egypt", International Conference : Future Vision and Challenges for
Urban Development, Cairo , Egypt, 20-22,2004

[7] Hanna, G.B., Guirguis, N.M.,Sheble,S.S., " ENERGY CODE FOR NEW OFFICE BUILDING", IIR Middle East Electricity Conference, Dubai,2005.

[8] Housing \& Building Research Center (HBRC), Code of Thermal Insulation, $3^{\text {rd }}$ edition Cairo-Egypt,2007.

[9] http://www.iea.org/g8/2008/Building_Codes.pdf, 2008.

[10] Institution of Heating \& ventilating Engineers Guide, Book A, 1970.Cairo-Egypt.

[11] K. F. Fong, C.K. Lee," Investigation On Hybrid System Design Of Renewable Cooling For Office Building In Hot And Humid Climate". Vol.75, 2014,PP 1-9.

[12] Karlsson, J.F., Moshfegh, B., "A comprehensive investigation of a low-energy building in Sweden", Renewable Energy 32, 1830-1841, 2007.

[13] Sheble, S.S., "Effect of window to wall ratio and different climate conditions on energy consumption for residential and commercial buildings in Egypt", Journal of Housing and Building National Research Centre (HBRC), Cairo Egypt, Vol 3 No. 2,2007.

[14] Virta1, M., Itkonen1, H.,Mustakallio1,P., Kosonen1,R., " Energy efficient HVAC-system and building design", Paper No. R5-TS29-OP05.CLIMA, Antalya, TURKEY,2010.

[15] Visual DOE 4.0 User Manual, August, 2004. http://www.archenergy.com

[16] Wang,L., Gwilliam, J., Jones, P., " Case study of zero energy house design in UK", Energy and Buildings, 41,12151222,2009 . 